\title{
Chapter 8 \\ Central Bankers as a Sociological Object: Stakes, Problems and Possible Solutions
}

\author{
Frédéric Lebaron and Aykiz Dogan
}

Central bankers can be defined as agents in charge of the decisions that are studied, developed and implemented within the central banks. These financial institutions have been both products and agents of nation-building and state formation (Cohen 1998; Feiertag and Margairaz 2016; Helleiner 1998), as well as that of the international diffusion of norms and structures (Krampf 2013; Marcussen 2005; Polillo and Guillén 2005). They are inserted and act in national and historical contexts, but they also share common functions (control of credit and money supply, banking and payment system supervision, reserve management, monetisation of budget deficit, collection and publication of data, etc.), objectives (price stability, macroeconomic and financial consistency), instruments (interest rates, open market operations, cash reserve ratio or other requirements and tools) and norms. Equipped with monopoly privileges such as issuing notes and acting as the final authority on monetary policy decisions, these institutions coordinate, in varying degrees, with governments. They also cooperate with each other as well as with regional, international and supranational decision-makers, some of which - such as the International Monetary Fund (IMF) and the Bank for International Settlements (BIS) - monitor and engage in policy coordination (Borio et al. 2008; Eichengreen et al. 2018; Toniolo 2005). In fact, in addition to being national policy-makers, central bankers have acquired a major role in the contemporary world economy and a central position in global governance (Baker 2006; Hall 2008).

In comparison with other sectors of public policy, monetary decisions are, in general, clearly identified and highly formalised. Furthermore, they are characterised by a very high degree of centralisation of decision power in the hands of a few

F. Lebaron $(\bowtie)$

Ecole normale supérieure Paris-Saclay, IDHES, Université Paris-Saclay, Cachan, France e-mail: frederic.lebaron@ens-cachan.fr

\section{A. Dogan}

University of Paris-1 Panthéon Sorbonne, UMR D\&S, IEDES, Paris, France 
people. This centralisation manifests itself even by the generalised use of the adjective 'central' to designate these institutions and by the small number of actors authorised to participate in official discussions and voting for policy formulation.

In a sense, it is easy to identify the individual actors in charge of the main monetary and financial decisions inside the central banks. They are officially appointed, most of the time by governments, as leaders of monetary policy councils. As their decisions have a direct impact on the economy, central bankers are situated in a structurally determining position which makes them both very visible and 'influential'. This is probably a central reason why a large set of professional actors (especially journalists, investors, traders and bankers) and a variety of 'experts' (including financial analysts and the so-called CB-watchers) consider individual central bankers as relevant 'objects' of interest, at least as much as government members or CEOs, although with rather specific features.

Central bankers are scrutinised, at the moment of their appointment in particular, by financial actors who try to gather information about their personal trajectories, previous position-takings and orientations in order to forecast their future behaviour as central bankers. They are present in the daily coverage of monetary policies, especially through the media image of the central bank 'governors' or 'chairmen', who are often described as powerful actors, sometimes even heroic in various ways. As a matter of fact, the press usually gives a nuanced and adjusted - though not entirely factitious -account of their work and achievements.

They have, furthermore, acquired prominence in a particular domain of scientific literature emanating from economists, who have begun to take seriously into consideration the variations in behaviours and discourses which relate to the variety of complex individual profiles that central bankers display. This paves the way for a more consistent sociological investigation of the group of central bankers, its internal differentiation and specificity.

In this contribution, we will focus on the construction of central bankers as an object of research and how this object can be methodologically approached. We will first (1) discuss the empirical sources that can be used for this purpose, then (2) make a descriptive analysis of the data on which our empirical study builds. We then proceed to (3) analyse central bankers as a social space and, further, (4) their position-takings as revelatory of their positions of power in this space.

\footnotetext{
${ }^{1}$ Designations of the heads of central banks vary across countries. The US 'chairman' corresponds to the 'gouverneur' of French-speaking countries or 'governor' at the Bank of England and banks in many English-speaking countries. The ECB has a 'president', who must be distinguished from the national 'governors' and the other members of the executive board. We will here use the word 'governor' in order to simplify.
} 


\section{Empirical Sources Currently Used in Research on Central Bankers}

Central banks are usually investigated on the basis of macroeconomic data, in particular using monetary and financial indicators (inflation, GDP growth, interest rates, exchange rates etc.). Most of the scientific work carried out on them is actually produced inside central banks or in academic economics departments particularly devoted to monetary macroeconomics and therefore close to central banks themselves. This tendency towards monopolisation highly contributes to their symbolic power as the sources of legitimate representations of the world. This knowledge production constitutes a semi-scientific field aiming at developing theoretical models and statistical testing of various aspects of central banking, which are part of the way modern economies function and contribute to defining economic realities.

Aside from socio-historical research on central banking (Feiertag and Margairaz 2010; Feiertag 2005), a growing number of studies call into question what we call the 'social process of neutralisation' in these institutions (Lebaron 2000a, b). Archival research as well as analyses on laws, jurisdictions, or other legal documents regulating this area have been important in investigating how central banks' specific powers are redefined (Mehra 2010; Smits 2015) and what effects they have on the 'financialisation' of economies (Krippner 2011). These powers have been at stake particularly in the debates about the 'independence' of these institutions from governments and about their growing 'regulatory' role, especially after the 2008 financial crisis (Canova 2015; Tognato 2013). An increasing number of case studies examine the monetary committees and decision-making processes, especially after the 'closed doors' to their secret meetings were slightly opened to researchers when certain central banks decided to publish transcripts and other documents from meetings (Bell-Kelton 2006). Central banks' claims for transparency also made ethnographic studies possible that were previously reserved to insiders (Smart 1999).

In parallel, we also observe a stronger interest for central bankers' discourses (Abolafia 2010; Holmes 2009; Rosenhek 2013) and their reinterpretation by the media (Velthuis 2015), in particular after the 'communicational turn' in central banking (Clévenot et al. 2015). Furthermore, on-site interviews complementing document analysis have been helpful in understanding some of the dynamics of the social space of central bankers, as well as certain 'field effects' (Mudge and Vauchez 2016). The personal trajectories and orientations of leading central bankers have also received growing attention, for instance from scholars who study trends in recruitment/appointment processes and their policy implications (Carré and Demange 2017; Chang 2003; Ennser-Jedenastik 2014; Marcussen 2006). By highlighting that the personal trajectories and characteristics of executive staff and directors influence the policy choices of central banks, these studies contribute to the deconstruction of the 'neutrality myth' (Adolph 2016).

Only recently have central bankers' biographical data also been more directly introduced into econometric analysis as explanatory factors and been recognised as a major scientific stake (Bordo and Istrefi 2018; Farvaque et al. 2009, 2011; 
Göhlmann and Vaubel 2007; Smales and Apergis 2016). In highly quantitative terms and sometimes with contradicting findings, these studies support that a central banker's biographical background, such as gender and educational or professional background, has an impact on monetary policy.

\section{A Descriptive Analysis of Central Bankers' Trajectories}

We now turn to a descriptive analysis of the data collected for our empirical study using a variety of sources (see also Lebaron 2008, 2010, 2012a, b, 2014, 2018a, b; Lebaron and Dogan 2016).

First, central bank governance is almost entirely reserved to male candidates. We have previously outlined a significant gender gap in monetary governance in our studies on the directors of central banks (Lebaron and Dogan 2018a; Lebaron 2016), as well as international monetary organisations, the IMF and the BIS (Lebaron and Dogan 2018b). Compared to 338 men (93\%), only 26 women (7\%) participated in monetary policy and decision-making as central bank governors in the period from 2000 to 2017. Among these 26 chairwomen, 24 were appointed after 2005 and 22 after 2008 , indicating still very small and insufficient progress since the crisis. There are so far very few studies on the long-neglected question of gender diversity in central bank governance and of the factors relating to women's (under-)representation, their policy implications and macroeconomic outcomes (Diouf and Pépin 2017; Farvaque et al. 2011; Masciandaro et al. 2015). Furthermore, these quantitative studies, based on sample populations of chairwomen too small to produce generalisable findings, don't allow us to perceive the complex mechanisms of exclusion and their consequences regarding gender inequality. Further qualitative research, in particular ethnographic, is required to better perceive the dynamics of 'masculine domination' in monetary governance, especially considering wide-ranging negative consequences, not limited to symbolic violence (Bourdieu 2002). In fact, Braunstein and Heintz have shown that monetary regimes and central bank policy have gender specific implications. Notably, they affect men's and women's employment differently, hence aggravating income gaps (Braunstein and Heintz 2008; Heintz 2006).

Secondly, most central bank governors are economists, and this is increasingly so. Among the 335 central bank governors in focus in our empirical study and for whom the information is available, only 55 do not have a degree in economics, while $84 \%$ have studied economics at the bachelor, master or PhD level. This is an increase in comparison with an earlier study from 1997 based on Who's who in central banking (Lebaron 2000b) that focused on central bank leaders of the 1990s. However, it should be noted that $29 \%$ of the central bank governors have a multidisciplinary profile. They might, for instance, have a bachelor degree in engineering, and an MBA and a PhD in economics. In order to cover such cases, the table we depart from and that comprises our empirical data (Table 8.1) counts three different fields for the disciplinary background of an individual. Management sciences are the second most prevalent discipline among the 334 central bank governors, and 71 have a degree in management, business administration, finance, commerce, 
Table 8.1 Fields of study (multiple responses were accepted); $\mathrm{N}=228$

\begin{tabular}{l|c|c|l}
\hline Field of study & Frequencies & $\begin{array}{l}\text { Percentages based on number } \\
\text { of responses }\end{array}$ & $\begin{array}{l}\text { Percentages based on number of } \\
\text { individuals }\end{array}$ \\
\hline Economics & 280 & $64.81 \%$ & $83.83 \%$ \\
\hline Management & 71 & $16.44 \%$ & $21.26 \%$ \\
\hline MEP & 26 & $6.02 \%$ & $7.78 \%$ \\
\hline Law & 26 & $6.02 \%$ & $7.78 \%$ \\
\hline $\begin{array}{l}\text { Political } \\
\text { science }\end{array}$ & 23 & $5.32 \%$ & $6.89 \%$ \\
\hline Sociology & 4 & $0.93 \%$ & $1.20 \%$ \\
\hline Other & 2 & $0.46 \%$ & $0.60 \%$ \\
\hline Total & 432 & $100.00 \%$ & \\
\hline
\end{tabular}

MEP Mathematics, engineering and physics

Table 8.2 Academic qualifications; $\mathrm{N}=327$

\begin{tabular}{l|c|c}
\hline & Frequencies & Percentages \\
\hline Postdoc & 1 & $0.31 \%$ \\
\hline PhD & 153 & $46.79 \%$ \\
\hline Master & 121 & $37.00 \%$ \\
\hline Bachelor & 53 & $16.21 \%$ \\
\hline No degree & 1 & $0.31 \%$ \\
\hline Total & 327 & $100.00 \%$
\end{tabular}

accounting or banking. The economists not only constitute an overwhelming majority, but they are more qualified too. Half of them have a $\mathrm{PhD}$, while this ratio is only $24 \%$ among those who studied other disciplines.

Table 8.2 gives a more general view of central bankers' academic backgrounds, providing frequencies and percentages for the highest academic qualifications of 327 central bank governors in the world during the period 2000 to 2017 . Considering the technocratic institutional discourse in the world of central banking, it might be surprising to see that not more than $47 \%$ have a PhD. Additionally, according to the data we have collected, 228 out of 336 governors of the world's central banks, which is a significant majority at $68 \%$, have studied in a foreign university. Those who studied abroad preferred US universities (54). The most frequented universities included, in decreasing order, Harvard University, Massachusetts Institute of Technology, University of Oxford, University of Illinois Urbana-Champaign, University of Pennsylvania (and its Wharton School of Business), Columbia University and London School of Economics.

Our findings also shed light on particular dimensions of this imbalance as regards in what regions of the world central bankers have done their studies abroad (Table 8.3). The American Federal Reserve (FED) chairmen, for example, all studied in the USA, hence none abroad; whereas the governors of the Bank of England all studied abroad (as well as in the UK). As for the European Central Bank (ECB) 
Table 8.3 Location of studies abroad in terms of regions (multiple responses were accepted); $\mathrm{N}=228$

\begin{tabular}{l|c|c|l}
\hline $\begin{array}{l}\text { Location of studies } \\
\text { abroad }\end{array}$ & Frequencies & $\begin{array}{l}\text { Percentages based on number } \\
\text { of responses }\end{array}$ & $\begin{array}{l}\text { Percentages based on number } \\
\text { of individuals }\end{array}$ \\
\hline USA & 122 & $45.69 \%$ & $53.51 \%$ \\
\hline UK & 55 & $20.60 \%$ & $24.12 \%$ \\
\hline Europe & 46 & $17.23 \%$ & $20.18 \%$ \\
\hline Canada & 10 & $3.75 \%$ & $4.39 \%$ \\
\hline Oceania & 10 & $3.75 \%$ & $4.39 \%$ \\
\hline Asia & 7 & $2.62 \%$ & $3.07 \%$ \\
\hline Middle-East & 7 & $2.62 \%$ & $3.07 \%$ \\
\hline Africa & 5 & $1.87 \%$ & $2.19 \%$ \\
\hline Latin America & 5 & $1.87 \%$ & $2.19 \%$ \\
\hline Total & 267 & $100.00 \%$ &
\end{tabular}

governors, 59\% didn't study abroad. For those who did, the first destination was again the USA (46\%), second the UK (39\%) and third Europe (19\%).

The over-representation of US universities in particular, and the universities of the Global North in general, underscores the asymmetric power relations in global monetary governance. We observe that candidates with a diploma from these universities have a better chance of reaching the top of the central bank hierarchy. In consequence, a considerable number of leading monetary policy makers in the world are formed in the Global North, hence importing and re-appropriating a certain epistemic perspective favoured in the educational institutions they attended. Even if there is a degree of diversity with regard to their political and scientific traditions, these universities produce the hegemonic knowledge that circulates in monetary authorities across the world, at least through their governors.

Central bank governors are mostly insiders in the institution where they uphold their positions and, more generally, in the field of finance; 130 out of 353 governors (37\%) have made their career in the central bank before becoming its governor. This percentage is much higher $(58 \%)$ for women, indicating that those who make a reputation inside the institution and pave their way up in the administrative hierarchy have a much higher chance than female outsiders to be considered as candidates for governance.

What goes for the central bankers is also valid for other actors in the finance field; $27.5 \%$ of the governors' main occupations have been in public financial administration. These institutions included the Treasury, Economy and Finance Ministries, financial supervisory bodies, public funds and so on. Moreover, 19\% of the governors are private bankers, traders, investors, CEOs or employees of financial companies, etc. Academics constitute $7 \%$ of the whole group, those with administrative careers $5 \%$ and politicians $3 \%$. The domination of economics-trained professionals of central banks is a recent feature, and it seems to have increased the link between the world of Anglo-Saxon finance and monetary decision-making, as foreseen in earlier studies (Lebaron 2000b). 


\section{A Social Space Approach}

A distinguishing feature of our analysis of the world of central bankers is that it departs from the idea that they constitute a particular social space. Pierre Bourdieu conceptualised this notion in the 1960s and onwards by emphasising the relationships between agents and groups in terms of the relative positions they occupy in the social world based on their volume and composition of different types of capital economic, cultural, symbolic, etc. (Bourdieu 1985, 1989). In our view, this is a general approach that can be applied to a very large variety of autonomous universes (Lebaron and Le Roux 2018).

To construct the space of the ECB Governing Council members, we applied a specific Multiple Correspondence Analysis (MCA) as explained by Le Roux and Rouanet (2010). This analysis was based on 62 individuals, 12 active questions and 32 active categories that we constructed from the answers to these questions with a view to produce a geometric modelling of the social space of the Governing Council during the period between 1999 and 2016. The questions and categories included sex, public visibility as measured by appearance in the Financial Times, educational level, educational field, main career, academic career, political career, career in the central bank, career in private finance, other private career, career in the administration and number of sectors during the career. We will only comment on the first two axes, as shown in the charts below. They represent a raw rate of variance of around $25 \%$ which is very high in MCA. ${ }^{2}$

Graph 8.1 shows the cloud of the most contributing active categories on the first axis. On the left side, we observe 'main career in administration' along with 'master's degree' and, below, 'financial career'. On the right, we see 'internal career' and 'central bank'. Hence, the first axis opposes internal versus financial and national administrative careers.

Graph 8.2 illustrates the categories building up the second opposition in the data, thus enabling us to complete the analysis. This second (vertical) axis opposes categories like 'financial administration', 'no academic career' and 'woman' at the top, versus 'research and university' and 'PhD' at the bottom. Whereas Axis 1 is a classical axis found in the space of central bankers, Axis 2 shows the growing importance of academic capital in this field, illustrated by the polarisation it creates in the case of Eurozone central bankers.

On one side, we find profiles strongly related to the academic world, whereas on the other side, we find 'practitioners' related to the politico-bureaucratic field, especially treasuries and ministries of finance. This opposition is particularly strong in countries where high civil servants have long since dominated the space of economic policy, as is the case in France and Germany, where the rise of academic Anglo-Saxon economics is more recent.

\footnotetext{
${ }^{2}$ Using other criteria such as Benzécri's modified rate lead to a maximum of three axes to interpret, with two clearly stronger first axes. We focus here on the first two axes, which are by far the most important and meaningful from both a statistical and sociological point of view.
} 


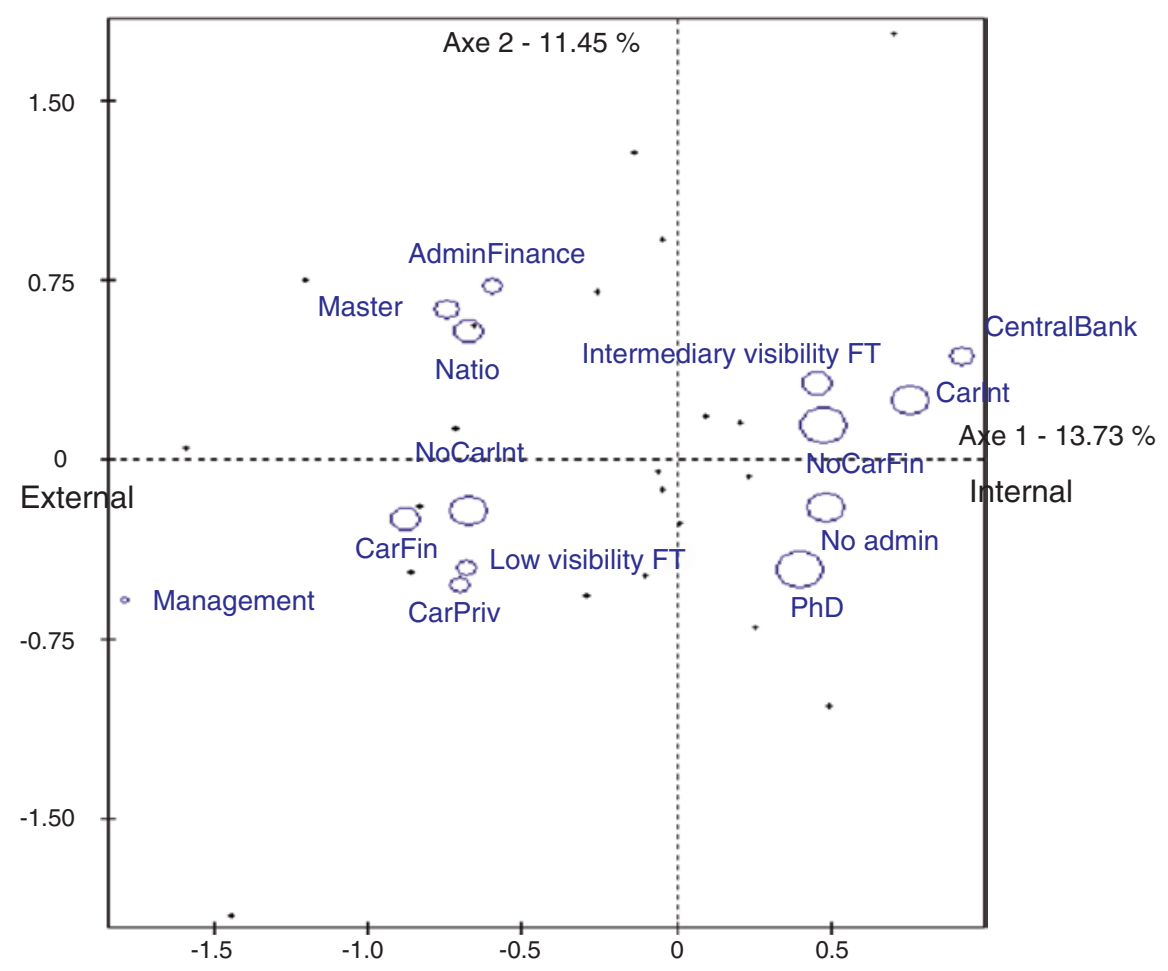

Graph 8.1 Cloud of the most contributing active categories - Axis 1

\section{Power in Process: A Sociology of Position-Takings}

At this point, our approach might seem as a purely descriptive, comparative account of the socio-demographics of the professional group of central bankers. While this is interesting in itself, at least in order to understand the objective basis of their centrality and powers, it does not enlighten us on how their relative positions relate to the policies they favour. We need to remember that 'powerful' actors are also agents whose position-takings or 'behaviours' have concrete effects on economic reality, for example through the influence over interest rates. More generally, monetary decisions are clearly connected to the effective powers that go along with having a position in this social space. We thus need to explore the link between positions in the field and what we refer to as 'position-taking'.

The categorisation of position-takings is embodied in the field itself, as we have previously observed in our studies on the field of economists (Lebaron 2000a, b) where a lot of lexical imagination is deployed to categorise its own members. Here, the opposition between 'doves' and 'hawks', which has a long history, is largely integrated in daily commentaries, especially at the Federal Reserve Bank. It is also common within the Eurozone. Before 2008, being a "hawk" means being 


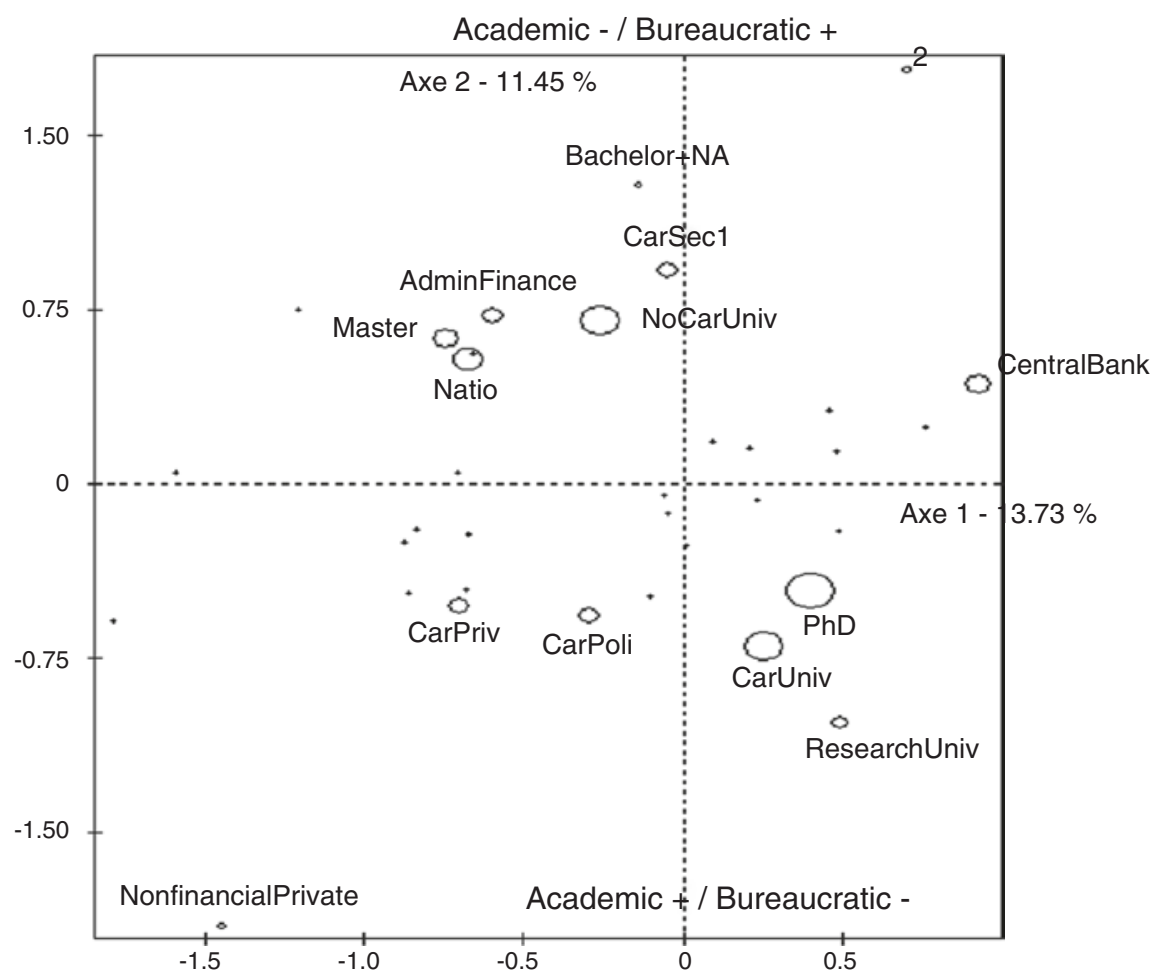

Graph 8.2 Cloud of the most contributing categories - Axis 2

particularly reluctant to a loosening of the monetary policy by fear of a rise of inflation. After 2008, being a "hawk," very consistently, means to oppose a radical adaptative strategy which uses a range of non-conventional measure in order to avoid a deepening of the financial crisis, which may give birth to later inflation. By opposition, the "doves" are the members of the committee which favor a certain degree of flexibility and loosening of the monetary policy, after 2008 in the context of the management of the global financial crisis, and before that in the context of low growth and high level of unemployment in the Eurozone. The MCA permits us to project categories representing position-takings as supplementary, i.e. not active, elements into the space of central bankers that we have created. As Graph 8.3 demonstrates, the second axis described above relates to an opposition between 'hawks' and 'doves', which are very well separated (more than 0.5 standard deviation) on this axis. In fact, it indicates that an academic background and the lack of political and bureaucratic capital is globally associated in this case with a more dovish orientation. Furthermore, position-taking categories indicating 'innovations' and 'change' suggest that such policy stands are connected to a more apparent support or commitment to innovation. In contrast to Axis 2 in the space, the first axis seems 


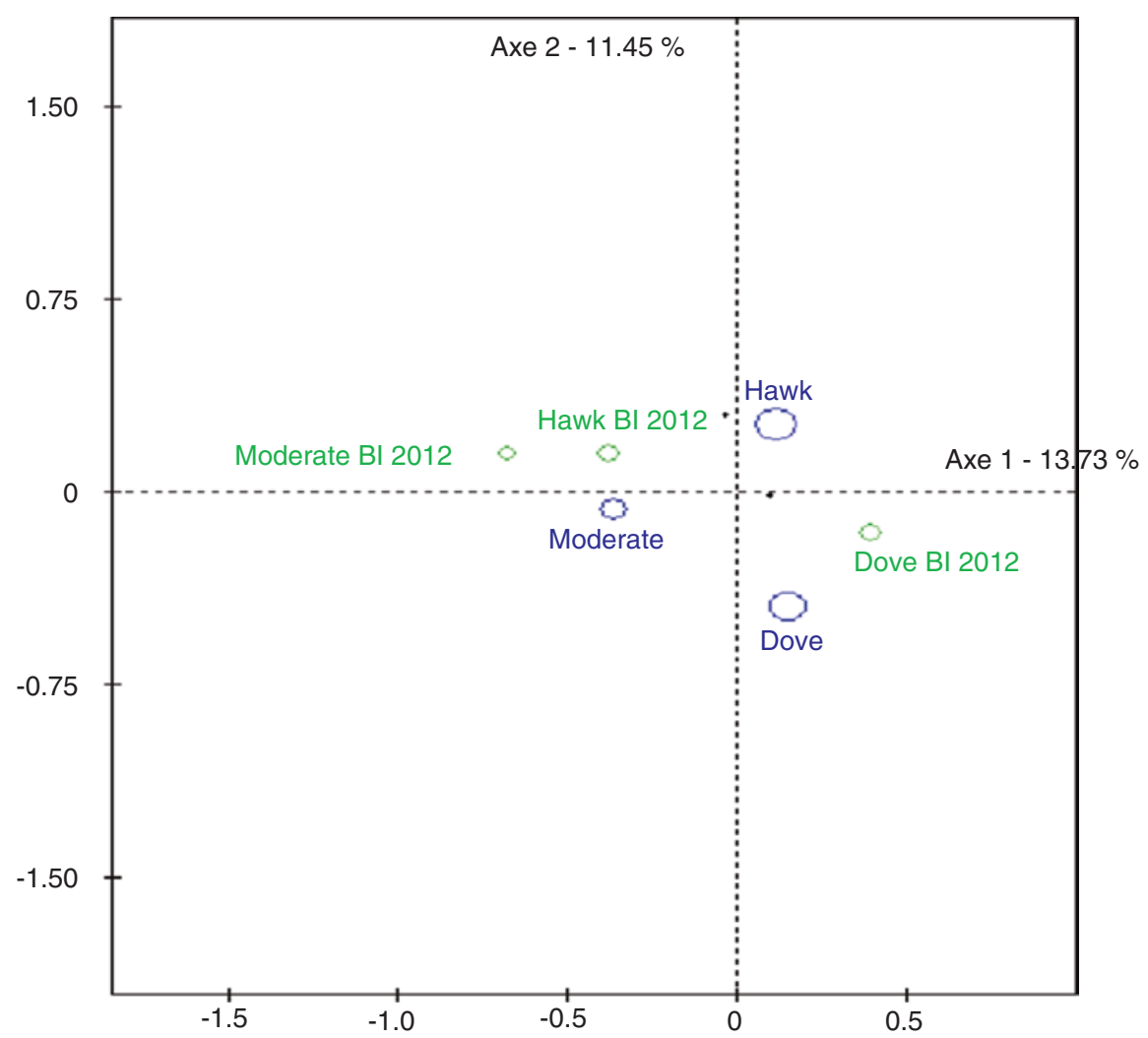

Graph 8.3 Supplementary categories of 'hawks' and 'doves'

to be rather weakly related to position-takings, with hawks slightly on the side of insider capital.

The MCA analysis permits us to also study the cloud of individuals whose properties and position-takings make up the space. Graph 8.4 shows that there is a high dispersion among the two groups of doves and hawks. Notice that the divisions are stronger in the group with higher levels of political and bureaucratic capital.

Our analysis of the cloud of individuals reveals how the internal political division of the Governing Council, which is confirmed by the publication of its minutes, relates to the professional and, more generally, the social characteristics of its members. On the 'resistance to innovation' side, one finds the German members (not all though, since Jörg Asmüssen typically represents a pragmatic stance), and also people like Yves Mersch and Erkki Liikanen, who could be seen as members of a 'German coalition' or 'German group' inside the Council. At the opposite side, there is the group supporting Mario Draghi by their declarations and votes, led by a very small number of actors with a high level of bureaucratic and political capital. This group is also supported by the (more silent) majority of national governors, more often coming from the universities. 


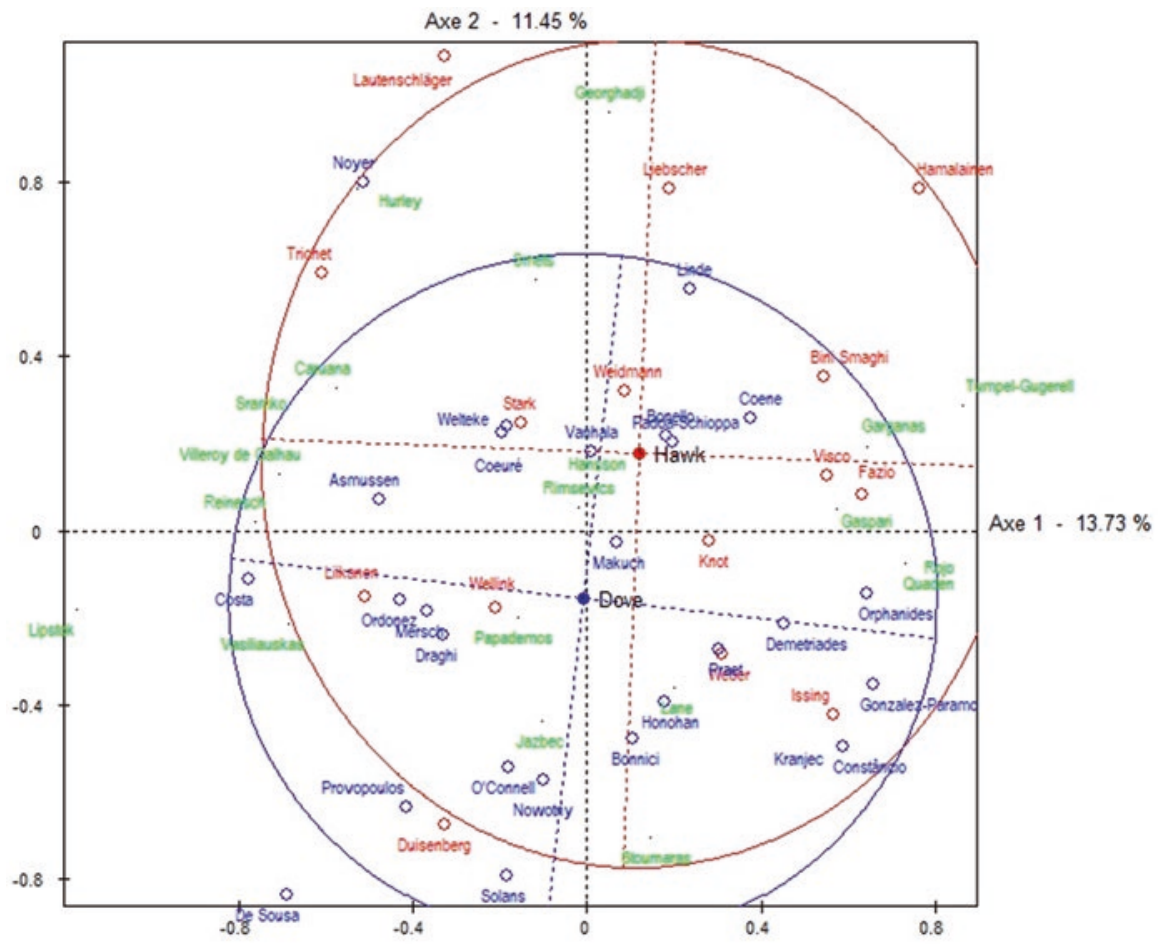

Graph 8.4 Cloud of individuals

To substantiate these results, we take the perspective of inductive data analysis (Le Roux and Rouanet 2004, 2010). Firstly, we assess the atypicality of 'hawks' on the second axis of the analysis. Are the characteristics of the hawks group similar to those of the reference population, or is the group atypical? In our Geometric Data Analysis framework, this question leads to permutation tests. We first compare the mean point of the sub-cloud of hawks with the corresponding reference point. By doing this, we cannot conclude, from an inductive point of view, that the hawks are atypical on the second axis. We found a similar result for the group of 'doves'. It is the deviation between both groups which is the most relevant here, first descriptively.

Hence, we secondly compare the mean points of two sub-clouds of 'hawks' and 'doves', assessing the homogeneity of the two groups for the second axis. It means that the deviation between the two mean-points is not due to chance. This leads to homogeneity tests. We can conclude from an inductive point of view that both groups are heterogeneous. The results are conclusive, even considering the number of individuals for whom we couldn't obtain the relevant information. The opposition between hawks and doves, then, is clearly connected to the second axis that opposes an academic pole to a more financial and bureaucratic pole. This finding is 
interesting, since this opposition has become a central pattern of differentiation inside monetary and financial elite, and more largely in the European field of power. ${ }^{3}$

Finally, position-takings can also be considered as discourses and analysed as such. Discourses are clearly at the heart of the symbolic power of central bankers, and numerous studies have insisted on their performative force (Callon 1998; MacKenzie et al. 2007). In the example illustrated below, we analyse 20 texts in French published as 'speeches' on the ECB's official website (Guilbert and Lebaron 2017). A first, more qualitative, part of the analysis aims at understanding the conditions of performativity of central bankers' discourses. The study of the space of words and texts, analysed with a simple correspondence analysis (511 words x 21 texts), reveals interesting patterns.

The example of metaphors shows how discourses serve to construct a certain representation of the world. Central bankers' discourses use numerous metaphors and often refer to the natural world or to daily-life activities such as driving a car. Their discourses share a set of properties, such as an objective of action or the use of semi-auxiliaries (such as 'should take action'). This intends at limiting potential misunderstandings or side-effects of discourses.

We show here the first two dimensions of the constructed space $(21.5 \%$ of the overall variance, which is very high in CA). The corpus comprises 20 texts, from which one large text has been cut in two, leading to 21 observations. For each text, we have gathered external information such as the date of production, the type of discursive situation, the place, the author, the nationality of the author, the status of the author, etc. This allows for a sociological analysis of the conditions of enunciation. Even if this lexicometric study does not offer a direct path to an analysis of position-takings properly speaking, it allows us to understand the semantic and social universes in which decision-makings are produced, hence to better grasp the logics of position-takings.

We see here in Graph 8.5 that the first axis relates to an opposition between contexts of enunciation, with more official international financial institutions on the left and more peripheral institutions on the right. The second opposition, however, on Axis 2 is clearly related to time, the 'self-referential' discourse being typical for the first period of the central bank and for economic audiences, whereas the most general political economy semantic world has gained in momentum after the crisis and is related to more external communication, especially directed towards political actors.

In Graph 8.6, which represents expressions used in the texts, the first axis opposes expressions like 'réforme structurelle', 'réformes' and 'reprise' on the left to words like 'devises', 'avoirs', 'monnaies' on the right, pointing to an opposition between economic policy and conjuncture analysis on the left and monetary-financial issues on the right. The second axis opposes expressions such as 'critique', 'stratégie', 'stabilité_des_prix' and 'conseil_des_gouverneurs' on the top to 'PME ',

\footnotetext{
${ }^{3}$ These results have been verified and enhanced by a use of combinatorial inference on the axes and on planes.
} 


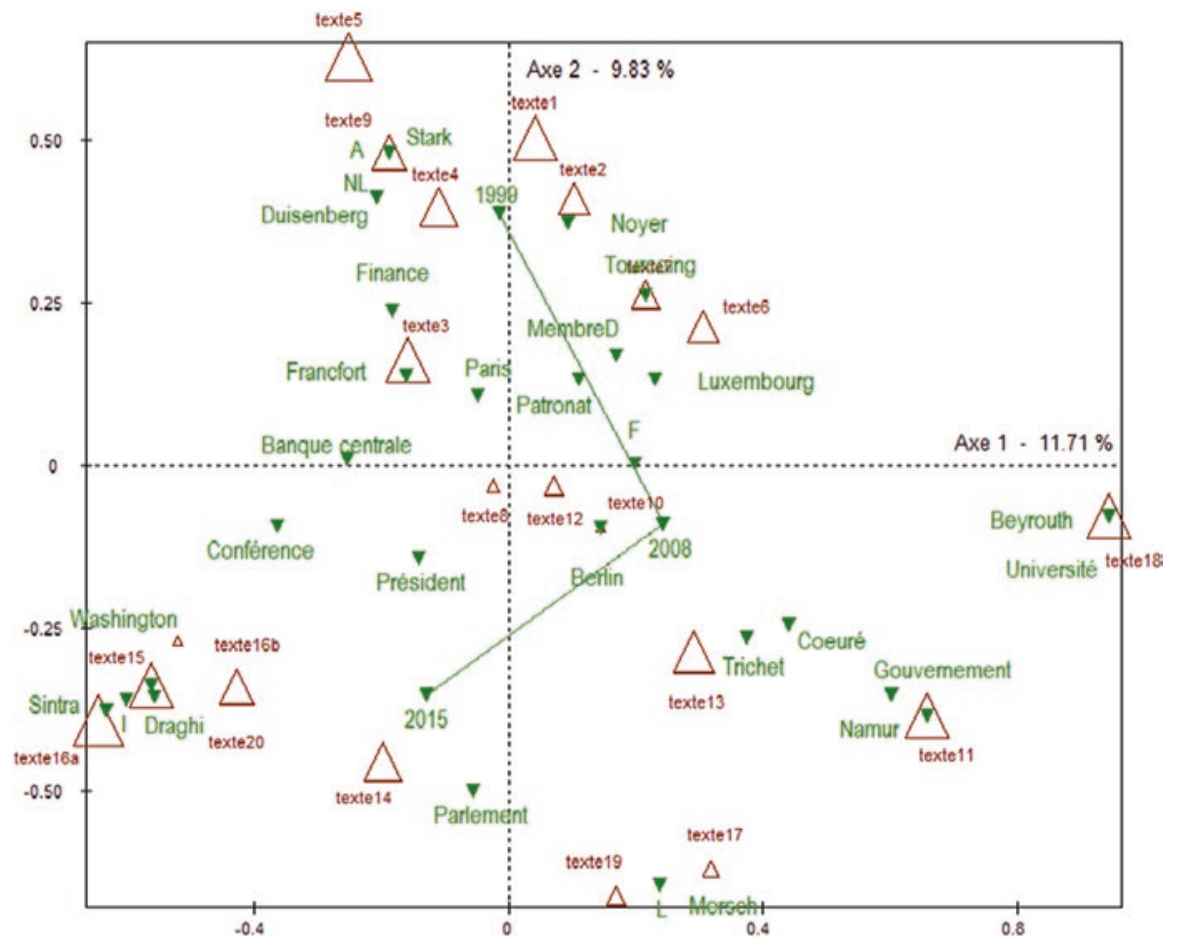

Graph 8.5 Cloud of texts

'souveraineté', and 'IDE' at the bottom. This represents and opposition between the general self-referential discourse of the central bank to more classical economic and political international and national issues.

\section{Conclusion}

Sociological investigations on central bankers make only a limited contribution to a more general sociology of finance, public policy, sociology of science and the study of transnational fields of governance. But it is of particular interest, since it is highly multidimensional as a research object and related to the three major spheres of activity in our society, namely science, economy and politics. The literature would benefit from studies that compare central bank leaders, directors of international financial organisations, ministers of finance and more influential government officials and various other subgroups of the 'public' pole of dominant classes. The major sociological stake is to understand the way governments and public authorities have become very close allies of economic and financially dominant groups, such as large company leaders and financiers, while maintaining a reference to scientific objectivity and universal goals such as the economic well-being of the people. 


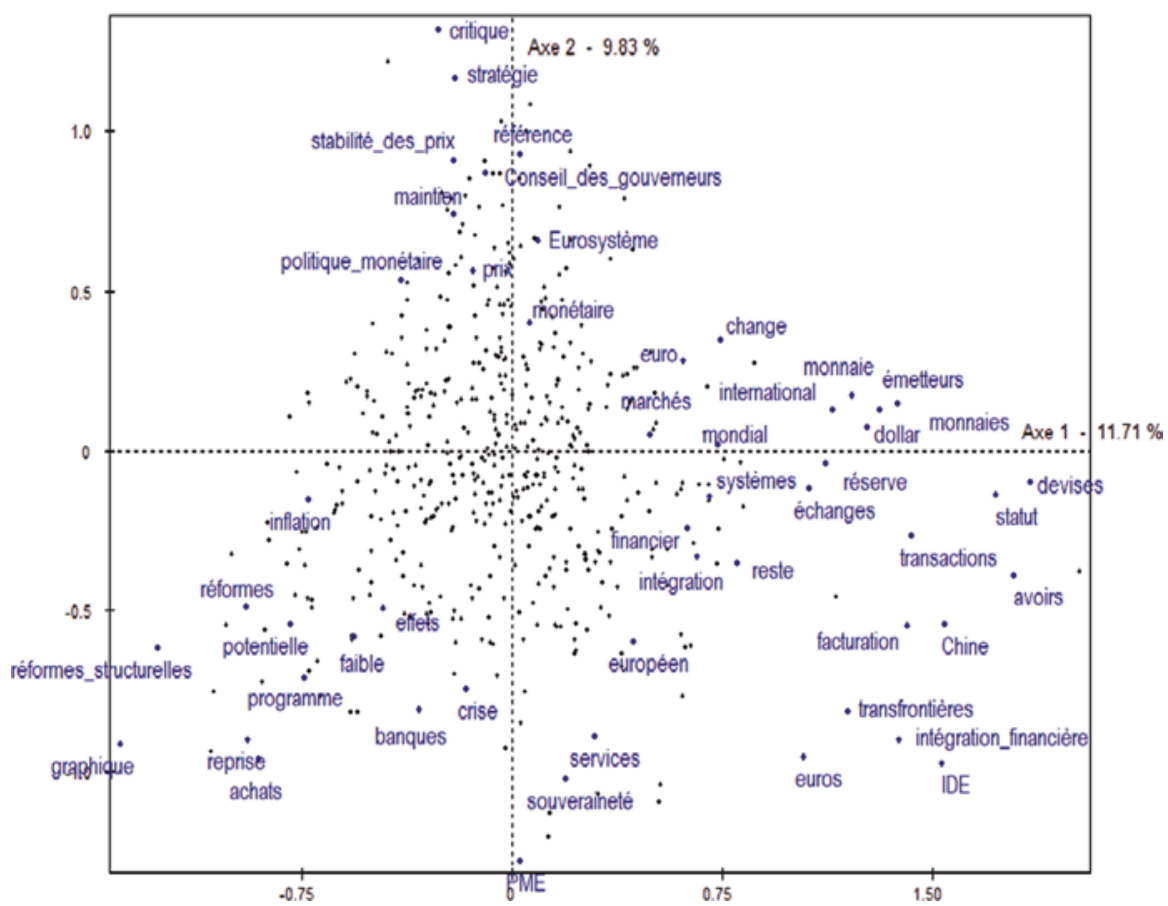

Graph 8.6 Cloud of expressions

\section{References}

Abolafia, M. Y. (2010). narrative construction as sensemaking: How a central bank thinks. Organization Studies, 31(3), 349-367.

Adolph, C. (2016). Bankers, bureaucrats, and central bank politics. Cambridge: Cambridge University Press.

Baker, A. (2006). The group of seven: Finance ministries, central banks and global financial governance. London: Routledge.

Bell-Kelton, S. (2006). Behind closed doors. The political economy of central banking in the United States. International Journal of Political Economy, 35(1), 5-23.

Bordo, M., \& Istrefi, K. (2018). Perceived FOMC: The making of Hawks, Doves and Swingers (Hoover Institution Economics Working Paper, Series 18108). Stanford: Hoover Institution.

Borio, C. E. V., Toniolo, G., \& Clement, P. (Eds.). (2008). Past and future of central bank cooperation. Cambridge: Cambridge University Press.

Bourdieu, P. (1985). The social space and the genesis of groups. Theory and Society, 14(6), 723-744.

Bourdieu, P. (1989). Social space and symbolic power. Sociological Theory, 7(1), 14-25.

Bourdieu, P. (2002). La domination masculine. Paris: Seuil.

Braunstein, E., \& Heintz, J. (2008). Gender bias and central bank policy: Employment and inflation reduction. International Review of Applied Economics, 22(2), 173-186. 
Callon, M. (1998). Introduction: The embeddedness of economic markets in economics. In M. Callon (Ed.), The laws of the markets (Sociological review monographs) (pp. 1-57). Oxford: Wiley.

Canova, T. A. (2015). The role of central banks in global austerity. Indiana Journal of Global Legal Studies, 22(2), 665-695.

Carré, E., \& Demange, E. (2017). La revolving door dans les banques centrales. Revue d'économie financière, 128(4), 233-254.

Chang, K. H. (2003). Appointing central bankers: The politics of monetary policy in the United States and the European Monetary Union (p. 2003). Cambridge: Cambridge University Press.

Clévenot, M., Desmedt, L., \& Llorca, M. (2015). Le Pouvoir Des Mots : Émission et Réception Du Discours Du Banquier Central. Économie et Institutions 22, no pagination.

Cohen, B. J. (1998). The geography of money. Ithaca/London: Cornell University Press.

Diouf, I., \& Pépin, D. (2017). Gender and central banking. Economic Modelling, 61, 193-206.

Eichengreen, B., Lombardi, D., \& Malkin, A. (2018). Multilayered governance and the international financial architecture: The erosion of multilateralism in international liquidity provision. Global Policy, 9(special issue), 7-20.

Ennser-Jedenastik, L. (2014). Party politics and the survival of central bank governors: Party politics and the survival of central bank governors. European Journal of Political Research, 53(3), $500-519$.

Farvaque, E., Hammadou, H., \& Stanek, P. (2009). Select your committee: The impact of central bankers' background on inflation. Economie Internationale, 1, 99-129.

Farvaque, E., Hammadou, H., \& Stanek, P. (2011). Selecting your inflation targeters: Background and performance of monetary policy committee members. German Economic Review, 12(2), 223-238.

Feiertag, O. (Ed.). (2005). Mesurer La Monnaie, Banques Centrales et Construction de l'Autorité Monétaire (XIXe-XXe Siècle). Paris: Albin Michel.

Feiertag, O., \& Margairaz, M. (Eds.). (2010). Gouverner une Banque Centrale: Du XVIIIe Siècle à Nos Jours. Paris: Albin Michel.

Feiertag, O., \& Margairaz, M. (Eds.). (2016). Les banques centrales et l'État-nation. Paris: SciencesPo.

Göhlmann, S., \& Vaubel, R. (2007). The educational and occupational background of central bankers and its effect on inflation: An empirical analysis. European Economic Review, 51(4), 925-941.

Guilbert, T., \& Lebaron, F. (2017). L'économie des mots et les mots de l'économie: analyse sociodiscursive des discours des dirigeants de la Banque centrale européenne. Langage et Societe, 2017(2-3), 217-235.

Hall, R. B. (Ed.). (2008). Central banking as global governance: Constructing financial credibility. Cambridge: Cambridge University Press.

Heintz, J. (2006). Globalization, economic policy and employment: Poverty and gender implications (Working Paper. Employment Strategy Paper 2006/3), ILO, Employment Strategy Department.

Helleiner, E. (1998). National currencies and national identities. American Behavioral Scientist, 41(10), 1409-1436.

Holmes, D. R. (2009). Economy of words. Cultural Anthropology, 24(3), 381-419.

Krampf, A. (2013). The life cycles of competing policy norms. Localizing European and developmental central banking ideas (KFG Working Papers, 49). Berlin: Freie Universität Berlin.

Krippner, G. (2011). Capitalizing on crisis: The political origins of the rise of finance. Cambridge, MA: Harvard University Press.

Le Roux, B., \& Rouanet, H. (2004). Geometric Data Analysis: From Correspondence Analysis to Structured Data Analysis. In Dordrecht. London: Kluwer Academic Publishers.

Le Roux, B., \& Rouanet, H. (2010). Multiple correspondence analysis. Thousand Oaks: Sage.

Lebaron, F. (2000a). La croyance économique. Les économistes entre science et politique. Paris: Seuil. 
Lebaron, F. (2000b). The space of economic neutrality. Trajectories and types of legitimacy of central bank managers. International Journal of Contemporary Sociology, 37(2), 208-229.

Lebaron, F. (2008) Central bankers in the contemporary global field of power: A 'social space' approach. Sociological Review, 56, monograph 1, "Remembering Elites", 121-144.

Lebaron, F. (2010). European central bank leaders in the global space of central bankers: A geometric data analysis approach. French Politics, 8(3), 294-320.

Lebaron, F. (2012a). ECB Leaders: A new European monetary elite? In D. Georgakakis \& J. Rowell (Eds.), The field of eucrocracy. Mapping EU actors and professionals. Basingstoke: Palgrave Macmillan.

Lebaron, F. (2012b). A universal paradigm of central banker? An inquiry based on biographical data. Social Glance, 1(1), 40-58.

Lebaron, F. (2014). Banquiers. In E. Lambert Abdelgawad \& H. Michel (Eds.), Dictionnaire des acteurs de l'Europe. Larcier: Bruxelles.

Lebaron, F. (2016). Les élites européennes comme champ(s). Réflexions sur les usages de la prosopographie et de l'analyse géométrique des données à partir de trois expériences de recherche collective sur des objets transnationaux. Cultures \& Conflits, 102, 139-162.

Lebaron, F. (2018a). Quand la critique académique entre dans l'Institution: réflexions sur la structure du champ des politiques économiques. Cultures \& conflits, 108, no pagination.

Lebaron, F. (2018b). Auto-biographical narratives and the social-historical science of economics: A contribution to reflexivity. Economic sociology_the european electronic newsletter, 19(2), 32-36.

Lebaron, F., \& Dogan, A. (2016). Do central banker's biographies matter?. Sociologica, 2/2016.

Lebaron, F., \& Dogan, A. (2018a). Social dimensions of monetary decisions, a study of the ECB Governing Council. In N. Champroux, G. Depeyrot, A. Dogan, \& J. Nautz (Eds.), Construction and deconstruction of monetary unions (pp. 147-164). Wetteren: Moneta.

Lebaron, F., \& Dogan, A. (2018b). Analysing biographies as social spaces: A new approach in the study of international organizations and the governance of money. Paper presented at the international conference Researching United Nations and Other IOs, University of Geneva, Switzerland, 18-20 June.

Lebaron, F., \& Le Roux, B. (2018). Bourdieu and geometric data analysis. In T. Medvetz \& J. J. Sallaz (Eds.), The Oxford handbook of Pierre Bourdieu. Oxford: Oxford University Press.

MacKenzie, D., FMuniesa, F., \& Siu, L. (2007). Do economist make markets? On the performativity of economics. Princeton: Princeton University Press.

Marcussen, M. (2005). Central Banks on the Move. Journal of European Public Policy, 12(5), 903-23.

Marcussen, M. (2006). Institutional transformation? The scientization of central banking as a case study. In T. Christensen \& P. Laegreid (Eds.), Autonomy and regulation: Coping with agencies in the modern state (pp. 81-109). Cheltenham: Edward Elgar.

Masciandaro, D., Profeta, P., \& Romelli, D. (2015). Gender and Monetary Policymaking: Trends and Drivers. SSRN Electronic Journal.

Mehra, A. (2010). Legal authority in unusual and exigent circumstances: The federal reserve and the financial crisis. University of Pennsylvania Journal of Business Law, 13, 221-273.

Mudge, S. L., \& Vauchez, A. (2016). Fielding supranationalism: The European central bank as a field effect. The Sociological Review Monographs, 64(2), 146-169.

Polillo, S., \& Guillén, M. F. (2005). Globalization pressures and the state: The worldwide spread of central bank independence. American Journal of Sociology, 110(6), 1764-1802.

Rosenhek, Z. (2013). Diagnosing and explaining the global financial crisis: Central banks, epistemic authority, and sense making. International Journal of Politics, Culture, and Society, 26(3), 255-272.

Smales, L. A., \& Apergis, N. (2016). The influence of FOMC member characteristics on the monetary policy decision-making process. Journal of Banking \& Finance, 64(Supplement C), 216-231. 
Smart, G. (1999). Storytelling in a central bank. Journal of Business and Technical Communication, 13(3), 249-273.

Smits, R. (2015). The crisis response in Europe's economic and monetary union: Overview of legal developments. Fordham International Law Journal, 38(4), 1133-1191.

Tognato, C. (2013). Central bank independence: Cultural codes and symbolic performance. New York: Palgrave Macmillan.

Toniolo, G. (2005). Central bank cooperation at the bank for international settlements, 1930-1973. Cambridge: Cambridge University Press.

Velthuis, O. (2015). Making monetary markets transparent: The European central bank's communication policy and its interactions with the media. Economy and Society, 44(2), 316-340.

Open Access This chapter is licensed under the terms of the Creative Commons Attribution 4.0 International License (http://creativecommons.org/licenses/by/4.0/), which permits use, sharing, adaptation, distribution and reproduction in any medium or format, as long as you give appropriate credit to the original author(s) and the source, provide a link to the Creative Commons license and indicate if changes were made.

The images or other third party material in this chapter are included in the chapter's Creative Commons license, unless indicated otherwise in a credit line to the material. If material is not included in the chapter's Creative Commons license and your intended use is not permitted by statutory regulation or exceeds the permitted use, you will need to obtain permission directly from the copyright holder.

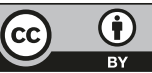

